\title{
Spiritual Lessons From the Coronavirus Pandemic
}

\author{
Curtis W. Hart ${ }^{1}$
}

Published online: 26 March 2020

(c) Springer Science+Business Media, LLC, part of Springer Nature 2020

This Editorial is being written from my study here in the Hudson Valley in Westchester County just north of New York City. Here I am, as I imagine many of you are, getting used to the "new normal" imposed by the pandemic of the coronavirus. It is a jarring process to get used to the restraint this puts upon us: no movies, no shopping trips, and no evenings out with friends. When we look at our current situation with the perspective now of about a week we realize that these inhibitions are at least for now not insurmountable. Meetings are held via ZOOM. There is a superabundance of e-mails from professional sources and contacts. We still can order out from local restaurants, and the post office makes deliveries of things we might need or want. But then we think, first, of those whose lives are truly imperiled beginning with those who have been infected and need care. And what about those who work at jobs that have or will soon disappear. We mourn for those who have yet to have gained a foothold in pursuit of the American dream and for their children. Our own children are grown, but we worry about what may happen to their children. And we look forward to a world here in our sophisticated suburban and urban America that in a relatively short time will look and act very differently. And we wonder.

I venture to say that those among our readers are undergoing this transformation in a variety of settings that may look different from the vantage point of our front window especially those in places truly far away from here. The international nature of those who read or contribute to the Journal makes me determined that even during this unnerving hiatus we continue to provide the sorts of articles and commentary that both challenge and undergird your work. As long as I am at this computer and have my internet access, we will go forward. I venture to add that were you to occupy this Editor's chair you would not hesitate to do the same were you similarly challenged.

One of my clergy colleagues here in New York who is the chaplain to Columbia University wrote an e-mail recently that perceptively identified one of the great hazards of these days as the boredom from not being able to act, to have moral agency, at least for these next important months, regarding an uncertain future that for Columbia students should be filled with promise and expectation of an unfolding

Curtis W. Hart

cuh9001@med.cornell.edu

1 New York, USA 
future. I thought this remark was spiritually and psychologically sound and worth marking in these pages. It is meant as an response and warning to any boredom that blocks us from contemplating new ideas, reinvigorated passions, and desires to strike out on new paths. My hope for all who read this is that our efforts here at the Journal will be a sure antidote to the boredom that stunts growth at all levels of personal and professional achievement. We will be here for the duration to make certain that we-authors, reviewers, Editorial Board members, and our wonderful colleagues at Springer-will be around when the crisis subsides.

Until then, if you have or write any articles or narratives about living through this virus, or even about the virus itself, please let us know so that we can consider a submission from you.

Publisher's Note Springer Nature remains neutral with regard to jurisdictional claims in published maps and institutional affiliations. 